\title{
Effect of Dietary Fiber on Endogenous Nitrogen Flows in Lactating Dairy Cows ${ }^{1}$
}

\author{
D. R. Ouellet, ${ }^{*}$ M. Demers, $\dagger^{2}{ }^{2}$, G. Zuur,‡ G. E. Lobley,§ J. R. Seoane, $\dagger$ \\ J. V. Nolan, $\|$ and H. Lapierre* \\ *Agriculture and Agri-Food Canada, Lennoxville, QC, J1M 1 Z3 Canada; \\ †Laval University, Ste-Foy, QC, G1K 7P4 Canada; \\ ¥Biomathematics and Statistics Scotland, Rowett Research Institute, Bucksburn, Aberdeen, AB21 9SB, UK; \\ §Rowett Research Institute, Bucksburn, Aberdeen, AB21 9SB, UK; \\ |University of New England, Armidale, NSW, Australia
}

\begin{abstract}
The effect of dietary fiber on endogenous $\mathrm{N}$ secretion was studied using a ${ }^{15} \mathrm{~N}$ isotope dilution technique in four fistulated Holstein cows. Two isonitrogenous diets differing only in fiber ( $\mathrm{NDF}$ and $\mathrm{ADF}$ ) content were used in a crossover design. One diet (HF) contained $37.4 \% \mathrm{NDF}$, while the other (LF) contained $23.3 \%$. A new model was developed to estimate endogenous $\mathrm{N}$ secretions and losses for the preintestinal, intestinal, and the total sections of the gastrointestinal tract. Three precursor pools: TCA-soluble fraction of plasma, intestinal mucosa, and milk were compared. Although endogenous losses estimated with the model were numerically different for each precursor pool selected (TCA-soluble fraction $>$ mucosa $>$ milk), treatment effects were similar. As intestinal mucosa is probably closest to the precursor pool, these data are discussed. Non-urea N endogenous secretions contributed $13 \%$ of the duodenal $\mathrm{N}$ flow but were not affected by the fiber content of the diet. The nonurea $\mathrm{N}$ endogenous flow at the duodenum was comprised of approximately equal inputs from endogenous $\mathrm{N}$ direct, and that incorporated into the microbial biomass. Total endogenous $\mathrm{N}$ flows at the duodenum exceeded, by nearly twofold, estimated inputs of urea-N to microbial biomass. Metabolic fecal output averaged $17 \%$ of fecal $\mathrm{N}$ and was not affected by level of dietary fiber, but net losses from secretions occurring in the small intestine were higher with the low fiber diet. Overall, endogenous $\mathrm{N}$ secretions represented $30 \%$ of total digestive tract protein synthesis.
\end{abstract}

(Key words: endogenous N, dietary fiber, isotope dilution technique)

Received February 13, 2002

Accepted April 15, 2002.

Corresponding author: D. Ouellet; e-mail: ouelletd@agr.gc.ca.

${ }^{1}$ Dairy and Swine Research and Development Center contribution No. 753.

${ }^{2}$ Actual address: Délimax Veaux Lourds Ltée. Saint-Hyacinthe (Québec) Canada J2S 8B1.
Abbreviation key: EN = endogenous N, HF = high fiber, $\mathbf{L F}=$ low fiber.

\section{INTRODUCTION}

Reducing wastage of $\mathrm{N}$ by dairy cattle requires close matching of feed supply to animal requirements. Determination of endogenous $\mathrm{N}(\mathbf{E N})$ losses allows for a better estimation of both supply and requirements. First, knowledge of EN losses permits estimation of real $\mathrm{N}$ digestibility, and is preferred to apparent digestibility to assess adequately the value of different feedstuffs, an approach often used in pigs (de Lange et al., 1992). Second, it is necessary to know how much additional dietary $\mathrm{N}$ is needed to cover the requirement for $\mathrm{EN}$ losses, which will comprise non-reabsorbed EN secretions. The EN secretions originate from saliva, gastric juices, bile, pancreatic secretions, sloughed epithelial cells, and mucin (Tamminga et al., 1995). Although the EN from both preintestinal and intestinal origin are largely reabsorbed in the small intestine, a substantial fraction may be eliminated in the feces (Van Bruchem et al., 1997). In addition, EN may also appear or disappear (via fermentation) within the large intestine.

Different methods have been used to determine EN losses in ruminants. Among these, the use of $\mathrm{N}$-free diets with intragastric infusion of VFA, (Ørskov and MacLeod, 1982, 1983) or application of regression approaches (Van Bruchem et al., 1989) have contributed towards a limited understanding of dietary effects on endogenous losses. Recently, distinction between feedderived and endogenous proteins has been addressed through the use of stable isotopes to permit evaluation of the secretion of EN (Tamminga et al., 1995).

Both DMI (Tamminga et al., 1995; Nyachoti et al., 1997) and fiber content of the diet (Zebrowska and Kowalczyk, 1991; Tamminga et al., 1995) affect the flow of EN into the intestine of both ruminants and nonruminants. For example, EN secretion increased by $0.04 \mathrm{~g}$ per $\mathrm{g}$ of additional fiber included in the diet of pigs (Tamminga et al., 1995). In sheep, effect of fiber is incon- 
sistent. While introduction of cellulose into the abomasum increased the $\mathrm{N}$ flow at the ileum by $17 \%$ (Zebrowska and Kowalczyk, 1991), other studies have failed to provide conclusive results on the effect of fiber per se (Van Bruchem et al., 1997). High-producing animals, such dairy cows, may have considerable EN losses associated both with the high intakes and with the amount of fiber present in the diet.

Therefore, the objective of this experiment was to determine the effect of high and low levels of dietary fiber on EN secretions and losses in preduodenal, intestinal, and total sections of the gastrointestinal tract in lactating dairy cows. Using a ${ }^{15} \mathrm{~N}$ isotope dilution technique, a new model was developed to take into account the unique aspect of the ruminant, to include the separate contributions of feed, recycled urea, and endogenous secretions to EN flows at the duodenum. The study also involved comparisons between three alternative precursor pools.

\section{MATERIALS AND METHODS}

The experimental conditions respected the guidelines of the Canadian Council on Animal Care (1993) and were approved by the Animal Care Committee of the Lennoxville Research Center.

\section{Cows and Treatments}

Four multiparous Holstein dairy cows, averaging 607 $\pm 21 \mathrm{~kg} \mathrm{BW}, 203 \pm 21 \mathrm{DIM}$, and $17.3 \pm 3.5 \mathrm{~kg} / \mathrm{d}$ of milk, were used in a crossover design to estimate the effect of dietary fiber on EN secretions and losses. Three cows were fitted with a duodenal cannula, and one was fitted with both duodenal and ileal cannulas (Berthiaume et al., 2001). The cannulas used were of the T-type as modified by Robinson and Kennelly (1990). Surgeries were performed at least 3 mo before the beginning of the experiment as they were used for another study before the current one started.

According to the crossover design, cows were fed a similar amount (DM basis) of two diets containing 23.3\% NDF (low fiber: LF) or 37.4\% NDF (high fiber: HF). To avoid feed refusals, the amount of DM offered to each cow was fixed at $90 \%$ of her average DMI measured before the beginning of the experiment. The diets (Table 1) contained grass, hay, and a mixture of corn-clover silage (50:50 on DM basis) supplemented with ground corn, soybean meal, and ground barley (for LF) or soybean hulls (for HF). The supplement was pelleted and fortified with minerals and vitamins to meet the NRC requirements (NRC, 1989). The CP and digestible energy contents of the diets were kept similar (Table 1). Chromium sesquioxide $\left(\mathrm{Cr}_{2} \mathrm{O}_{3}\right)$, used as a marker, was
Table 1. Ingredient and nutrient composition of the two experimental diets (\% DM) with high (HF) or low (LF) fiber content.

\begin{tabular}{lrrrr}
\hline & \multicolumn{2}{c}{ Diets } & & \\
\cline { 2 - 3 } Ingredients, \% of diet & \multicolumn{1}{c}{ HF } & LF & SEM & $P^{1}$ \\
\hline Corn:clover silage (50:50) & 34.0 & 34.7 & & \\
Grass hay & 2.9 & 3.0 & & \\
Ground corn & 13.2 & 13.2 & & \\
Soybean meal & 11.5 & 11.5 & & \\
Ground barley & 0.0 & 35.7 & & \\
Soybean hulls & 36.4 & 0.0 & & \\
Minerals and vitamins & \\
Chemical composition & & & \\
CP (\% DM) & 2.0 & 1.9 & & \\
ADF (\% DM) & & & & NS \\
NDF (\% DM) & 17.4 & 17.6 & 0.4 & 0.01 \\
Digestible energy (MJ/kg) & 26.2 & 13.4 & 0.02 & 0.02 \\
\hline
\end{tabular}

${ }^{1} \mathrm{NS}$, not significant, $P>0.10$.

${ }^{2}$ Contains: $21.8 \% \mathrm{NaCl} ; 14.0 \% \mathrm{Ca} ; 7.3 \% \mathrm{P} ; 2.2 \% \mathrm{Mg} ; 0.06 \% \mathrm{~K} ; 0.5 \%$ $\mathrm{S} ; 660 \mathrm{mg} / \mathrm{kg}$ of Cu; $2215 \mathrm{mg} / \mathrm{kg}$ of Mn; $3322 \mathrm{mg} / \mathrm{kg}$ of Zn; $13 \mathrm{mg} / \mathrm{kg}$ of Se; $5411 \mathrm{mg} / \mathrm{kg}$ of Fe; 298,900 UI/kg of Vitamin A; 100,900 UI/kg of Vitamin D; $1006 \mathrm{UI} / \mathrm{kg}$ of Vitamin E.

${ }^{3}$ Least square means ( $\mathrm{HF}, \mathrm{n}=3$; $\mathrm{LF}, \mathrm{n}=4$ ) and SEM given for $\mathrm{n}$ $=3$.

mixed with the supplement to provide a daily intake of $30 \mathrm{~g}$ of $\mathrm{Cr}_{2} \mathrm{O}_{3}$ per cow. The hay was offered at $1000 \mathrm{~h}$, and the remaining of the diets was served as a TMR in 12 equal meals delivered every other hour using automatic feeders (Ankom, Fairport, NY). The DM content of each silage was estimated weekly to fix the DM offered through the experiment. Amount of feed offered and orts, when applicable, were recorded daily. Cows were weighed at the beginning and at the end of each period. They were milked twice daily at 0700 and 1900 $\mathrm{h}$, and the production was recorded.

\section{Sample Collection}

Each period of the crossover lasted for $24 \mathrm{~d}$. The first $16 \mathrm{~d}$ allowed adaptation to the diets. Polyvinyl catheters were inserted into two contralateral jugular veins on d 15. The next day, L- $\left[{ }^{15} \mathrm{~N}\right]$ leucine (99 atom \%, ACP, Montreal, Canada) was infused continuously (0.57 $\mathrm{mmol} / \mathrm{h}$ ) into one of the jugular veins with peristaltic pumps (Masterflex pump, model 7523-30; ColeParmer Instrument Co.) during $200 \mathrm{~h}$, from d 16 to 24 . Samples of blood, intestinal mucosa, and duodenal digesta were taken at $0900,1200,1500$ and $1800 \mathrm{~h}$ on d 23 and at $0800,1100,1400$, and $1700 \mathrm{~h}$ on d 24 . Total feces and urine were collected from d 16 to 24 , and representative daily samples were prepared for analyses. Milk samples were obtained at each milking from d 13 to 24 .

\section{Sample Handling}

Portions of fresh blood $(10 \mathrm{ml})$ samples were immediately centrifuged at $3000 \times \mathrm{g}$ for $12 \mathrm{~min}$ at $4^{\circ} \mathrm{C}$, and the 
plasma obtained was kept frozen at $-20^{\circ} \mathrm{C}$ for further analyses. Digesta $(500 \mathrm{ml})$ was harvested via the Ttype closed cannula using a tube that deflected all the digesta present at the entry of the cannula into the collection bottle. The digesta, kept on ice less than 30 min, was separated as follows: Two subsamples were saved, frozen as collected, and the remainder was squeezed through four layers of cheesecloth. A subsample of the filtrate was kept frozen until analyzed, and the remainder was refrigerated at $4^{\circ} \mathrm{C}$ for bacteria isolation. Within $24 \mathrm{~h}$, bacteria were isolated by differential centrifugation according to the procedure of Smith and McAllan (1974), except that the first centrifugation was at $1000 \times g$. The final sediment was frozen at $-20^{\circ} \mathrm{C}$ for subsequent analyses.

One portion of each milk sample was immediately frozen at $-20^{\circ} \mathrm{C}$, while a second portion was kept at $4^{\circ} \mathrm{C}$ using bronopol as a preservative, and shipped weekly for determination of fat, protein, lactose, and urea using near-infrared procedures (Bentley 2000; Bentley Instrument, Inc., Chaska, MN, USA) at the DHI laboratory (PATLQ, Ste-Anne-de-Bellevue, QC).

A 500-g representative sample of each daily feces was frozen at $-20^{\circ} \mathrm{C}$ for later analyses. Urine was collected in stainless steel containers via a Gooch tube (BF Goodrich Co., Kitchener, ON, Canada) attached to the vulva of the cow with nylon netting covered with neoprene (Spall Bowan, Ltd., Guelph, ON, Canada). Urine was acidified daily with $120 \mathrm{ml}$ of concentrated $\mathrm{H}_{2} \mathrm{SO}_{4}$. Subsamples $(250 \mathrm{ml})$ of urine were taken each day and kept frozen until analysis.

Intestinal mucosa samples were taken with an optical fiber endoscope (Olympus CF type P10L, Olympus Co., Ltd., Tokyo, Japan) introduced in a distal direction at approximately $20 \mathrm{~cm}$ from the opening of the duodenal cannula. Three samples ( $5 \mathrm{mg}$ each on wet basis) from the same area were taken with the sampling forceps. The samples were immersed in a plastic bag filled with saline $(0.9 \% \mathrm{NaCl})$; the saline was later discarded and the samples frozen until further analysis.

\section{Chemical Analyses}

Dry-matter content of feed and orts was determined by oven-drying at $50^{\circ} \mathrm{C}$ and that of bacteria, feces, and digesta by freeze-drying (Freezemobile 24, Virtis, Gardiner, NY) to a constant weight. Feces, feed, and orts were ground at $0.5 \mathrm{~mm}$ with a laboratory mill (Arthur H. Thomas Co., Philadelphia, PA). Digesta was also ground at $0.5 \mathrm{~mm}$ using a Cyclotec 1093 sample mill (Tecator, Hoganas, Sweden). Bacteria were mashed with a pestle and a mortar. Plasma samples for ${ }^{15} \mathrm{~N}$ enrichment determination were prepared according to the following method: $0.3 \mathrm{ml}$ of $10 \%(\mathrm{w} / \mathrm{v})$ trichloroacetic acid (TCA) was added to $0.5 \mathrm{ml}$ of plasma to separate the soluble from the insoluble TCA fractions (Read et al., 1981). The solution was mixed and kept overnight at $4^{\circ} \mathrm{C}$. The solution was then centrifuged at $3000 \times g$ for $20 \mathrm{~min}$ at $4^{\circ} \mathrm{C}$. The supernatant was neutralized with $0.1 \mathrm{~N} \mathrm{NaOH}$ and centrifuged at $3000 \times g$ for 20 $\min$ at $4^{\circ} \mathrm{C}$. The second supernatant was freeze-dried for ${ }^{15} \mathrm{~N}$ analysis and referred as TCA-soluble plasma $\mathrm{N}$ fraction. Chromium oxide analysis on feed, feces, and digesta was conducted according to the procedure of Fenton and Fenton (1979). Total N concentration of feed and orts was determined with a Leco apparatus (Leco FP-428, Leco Corp., St. Joseph, MI), and N content of the other materials was quantified with a $\mathrm{N}$ analyzer 1500 (Carlo Erba Strumentazione, Italy).

The ${ }^{15} \mathrm{~N}$ enrichment analyses were performed in duplicate on individual samples taken on each of d 23 and 24. Dried samples were analyzed for feed, digesta, bacteria, feces, and TCA-soluble plasma N fraction, while enrichment of mucosa, milk, and urine were determined on samples as collected. Analyses of ${ }^{15} \mathrm{~N}$ enrichment were performed by total combustion using an elemental analyzer (Carlo Erba Strumentazione NA 1500 , Italy) coupled to a isotope ratio mass-spectrometer (SIRA 12, VG Isogas, Middlewitch, Cheshire, England). Urinary purine derivatives were analyzed after heating at $60^{\circ} \mathrm{C}$ to solubilize crystallized uric acid according to the procedure of Barcells et al. (1992) with a Beckman dual-pump Beckman HPLC system (Beckman system Gold, Beckman Instruments, Inc., Fullerton, CA). Gross energy in dry feed, dry feces, and urine samples was determined with an adiabatic bomb calorimeter (model 1241; Parr Instrument Co., Moline, IL). Urinary energy analysis was conducted on a $25-\mathrm{ml}$ sample weighed in a preweighed calorimetric bag, freezedried, and reweighed. The ADF and NDF content of feces and feed were quantified according to the procedure of Van Soest et al. (1991) using a Fibertec system I (Tecator, Hoganas, Sweden).

\section{Measurements of Digesta Flows}

The DM flow at the duodenum was estimated with $\mathrm{Cr}_{2} \mathrm{O}_{3}$. The following equation was used to calculate the DM flow (Bondi, 1987):

$$
\begin{gathered}
\text { DM flow } \text { duodenum }(\mathrm{g} / \mathrm{d}) \\
=\frac{\mathrm{Cr}_{2} \mathrm{O}_{3} \text { in feed }(\mathrm{mg} / \mathrm{g} \text { of } \mathrm{DM}) \times \mathrm{DMI}}{\mathrm{Cr}_{2} \mathrm{O}_{3} \text { in duodenal digesta }(\mathrm{mg} / \mathrm{g} \text { of } \mathrm{DM})}
\end{gathered}
$$

Bacterial $\mathrm{N}$ entering the duodenum (g of $\mathrm{N} / \mathrm{d}$ ) was estimated using purine derivatives excreted in urine and milk (Chen and Gomez, 1992): 
microbial $\mathrm{N}=\mathrm{PA} \times 70 \div(0.116 \times 0.83 \times 1000)=$

$$
\mathrm{PA}=\left(\begin{array}{l}
0.727 \times \mathrm{PA} \\
\left.\mathrm{PD}_{\text {urine }}+\mathrm{PD}_{\text {milk }}-0.385 \times \mathrm{W}^{0.75}\right) \div 0.85,
\end{array}\right.
$$

where $\mathrm{PA}=$ purine absorption $(\mathrm{mmol} / \mathrm{d})$ and $\mathrm{PD}_{\text {urine }}=$ purine derivatives $(\mathrm{mmol} / \mathrm{d})$ excreted in urine. The $\mathrm{PD}_{\text {milk }}=$ purine derivatives $(\mathrm{mmol} / \mathrm{d})$ excreted in milk which was estimated as $1 \mathrm{mmol} / \mathrm{kg}$ of milk (Chen and Gomez, 1992). The following assumptions were used: The true digestibility of microbial purines is 0.83 , the $\mathrm{N}$ content of purine is $70 \mathrm{mg} \mathrm{N} / \mathrm{mmol}$, and the ratio of purine-N:total $\mathrm{N}$ in mixed rumen microbes is 11.6:100 (Chen and Gomez, 1992). In the PA equation, 0.385 represents the endogenous contribution of purines and 0.85 is the recovery of absorbed purines as PD in urine and milk.

\section{Model Calculations}

Continuous infusion of $\left[{ }^{15} \mathrm{~N}\right]$ leucine for several days results in labeling of proteins throughout the body. As a consequence, EN secretions into the gut will be enriched in ${ }^{15} \mathrm{~N}$. In ruminants, the sources of ${ }^{15} \mathrm{~N}$ label in digesta and feces comprise (i) "free" EN (mainly protein), (ii) EN used to support microbial protein synthesis, and (iii) urea-N produced in the body, returned to the gut, and used again as a source of microbial $\mathrm{N}$. These different contributions need to be considered and introduce complexities compared with the simple dilution of ${ }^{15} \mathrm{~N}$ in feces in nonruminants, such as pigs (de Lange et al., 1990). Here, a model is presented that (i) separates endogenous secretions into pre- and postduodenal origins (fore-stomach and intestine models, respectively), and (ii) separates urea- $\mathrm{N}$ secretions into the rumen from endogenous secretions.

Basic model for endogenous flows. Let the section of the gastro-intestinal tract of interest start at $\mathrm{x}$ and end at $\mathrm{y}$ (e.g., $\mathrm{x}=$ duodenum and $\mathrm{y}=$ feces). The $\mathrm{N}$ present at y $\left(\mathrm{F}_{\mathrm{y}}\right)$ is assumed to be derived from only two sources, namely (i) nonabsorbed digesta-N from $\mathrm{x}$ $\left(F_{y, x}\right)$, and (ii) EN secretions into the tract between $x$ and $\mathrm{y}$ which were not reabsorbed $\left(\mathrm{F}_{\mathrm{y}, \text { end }}\right)$ :

$$
\mathrm{F}_{\mathrm{y}}=\mathrm{F}_{\mathrm{y}, \mathrm{x}}+\mathrm{F}_{\mathrm{y}, \text { end }}
$$

Let $\mathrm{E}_{\mathrm{x}}$ and $\mathrm{E}_{\mathrm{y}}$ denote the ${ }^{15} \mathrm{~N}$ enrichments of the digesta at $\mathrm{x}$ and $\mathrm{y}$, respectively, and let $\mathrm{E}_{\text {end }}$ denote the ${ }^{15} \mathrm{~N}$ enrichment of EN secretions into the tract. As for total $\mathrm{N},{ }^{15} \mathrm{~N}$ in the digesta at $\mathrm{y}\left(\mathrm{E}_{\mathrm{y}} \times \mathrm{F}_{\mathrm{y}}\right)$ is also assumed to have come from (i) nonabsorbed digesta- ${ }^{15} \mathrm{~N}$ from $\mathrm{x}\left(\mathrm{E}_{\mathrm{x}} \times \mathrm{F}_{\mathrm{y}, \mathrm{x}}\right)$, and (ii) nonreabsorbed endogenous- ${ }^{15} \mathrm{~N}$ secreted into the tract between $\mathrm{x}$ and $\mathrm{y}\left(\mathrm{E}_{\text {end }} \times \mathrm{F}_{\mathrm{y} \text {,end }}\right)$ :

$$
\mathrm{E}_{\mathrm{y}} \times \mathrm{F}_{\mathrm{y}}=\mathrm{E}_{\mathrm{x}} \times \mathrm{F}_{\mathrm{y}, \mathrm{x}}+\mathrm{E}_{\text {end }} \times \mathrm{F}_{\mathrm{y}, \text { end }}
$$

Solving (1) and (2) for the unknown variables $\mathrm{F}_{\mathrm{y}, \mathrm{x}}$ and

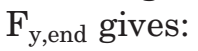

$$
\begin{gathered}
\mathrm{F}_{\mathrm{y}, \text { end }}=\frac{\mathrm{E}_{\mathrm{y}}-\mathrm{E}_{\mathrm{x}}}{\mathrm{E}_{\mathrm{end}}-\mathrm{E}_{\mathrm{x}}} \times \mathrm{F}_{\mathrm{y}} \\
\mathrm{F}_{\mathrm{y}, \mathrm{x}}=\mathrm{F}_{\mathrm{y}}-\mathrm{F}_{\mathrm{y}, \text { end }}
\end{gathered}
$$

This forms the basic isotope dilution model for calculation of endogenous flows and can be applied to any section of the tract. For example, de Lange et al. (1990) take $\mathrm{x}=$ feed and $\mathrm{y}=$ ileal digesta to calculate endogenous losses across the stomach and small intestine of pigs.

Equation (2) describes the contribution of the various ${ }^{15} \mathrm{~N}$ sources to ${ }^{15} \mathrm{~N}$ found in the digesta at $\mathrm{y}$. This general form of equation is useful in that enrichments expressed as atom percent (AT\%) or atom percent excess (APE) can be applied. In this paper, all model calculations are based on ${ }^{15} \mathrm{~N}$ enrichments (E) expressed as AT\%, while flows (F) are in $\mathrm{g} \mathrm{N} / \mathrm{d}$.

\section{Intestine Model}

The model defined by equations (1) through (4) can be applied to the intestine by taking $\mathrm{x}=$ duodenum and $y=$ feces (see Figure 1). The measured quantities are fecal $\mathrm{N}$ flow $\left(\mathrm{F}_{\mathrm{fec}}\right)$, and the ${ }^{15} \mathrm{~N}$ enrichments of duodenal digesta $\left(\mathrm{E}_{\mathrm{duo}}\right)$, feces $\left(\mathrm{E}_{\mathrm{fec}}\right)$, and endogenous secretions $\left(\mathrm{E}_{\mathrm{end}}\right)$. The latter is not measured directly, but values from the ${ }^{15} \mathrm{~N}$ enrichment of either milk, duodenal mucosa, or the TCA-soluble plasma fraction were taken as representative of the "true" precursor pool(s), in line with the general approach adopted elsewhere (Lien et al., 1997; Bartelt et al., 1999). The two unknown quantities are $\mathrm{F}_{\text {fec,end, }}$, the fecal $\mathrm{N}$ flow originating from postduodenal EN secretions, and $\mathrm{F}_{\text {fec,duo, }}$, the undigested duodenal digesta- $\mathrm{N}$ in feces. These are obtained from (3) and (4), as follows:

$$
\begin{aligned}
& F_{\text {fec,end }}=\frac{E_{\text {fec }}-E_{\text {duo }}}{E_{\text {end }}-E_{\text {duo }}} \times F_{\text {fec }} \\
& F_{\text {fec,duo }}=F_{\text {fec }}-F_{\text {fec,end }}
\end{aligned}
$$

\section{Forestomach Model}

In principle, the basic model given by (1) through (4) can also be applied to the rumen by setting $\mathrm{x}=$ feed and $\mathrm{y}=$ duodenum. This would ignore, however, that secretions into the rumen also include urea- $\mathrm{N}$ in addition to EN. These sources of secretion will enter the rumen at different enrichments. Therefore, the basic model requires extension. In addition, EN can be present in digesta both in "free" form and as a source of 


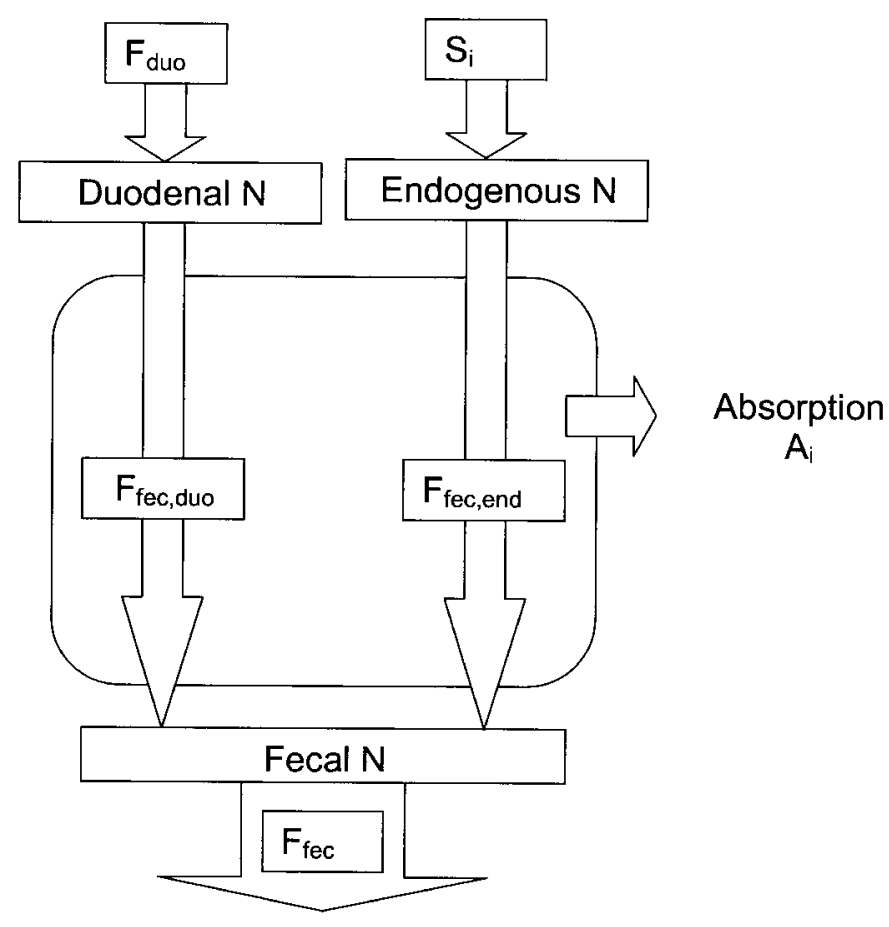

Figure 1. Intestine model. $F_{x}$, flow of $N$ at site $x ; F_{y, x}$, flow of $N$ to pool y from pool $\mathrm{x}$. Entry of $\mathrm{N}$ into the intestine is the summation of $\mathrm{N}$ flow at the duodenum $\left(\mathrm{F}_{\text {duo }}\right)$ plus endogenous secretion from the intestine $\left(\mathrm{S}_{\mathrm{i}}\right)$. Flow of $\mathrm{N}$ in the feces $\left(\mathrm{F}_{\text {fec }}\right)$ is separated into $\mathrm{N}$ derived from undigested duodenal digesta $\left(\mathrm{F}_{\text {fec,duo }}\right)$ and undigested free $\mathrm{N}$ derived from endogenous secretions into the intestine $\left(\mathrm{F}_{\text {fec,end }}\right)$. All $\mathrm{N}$ fractions leaving the intestine, other than in feces, are defined as absorbed $\left(\mathrm{A}_{\mathrm{i}}\right)$.

bacterial N. Nitrogen in the duodenal digesta that is derived from urea is assumed to be present only in bacterial N. Based on these considerations, the general model is then expanded as follows (see also Figure 2).

First, the duodenal $\mathrm{N}$ flow $\left(\mathrm{F}_{\text {duo }}\right)$ is separated into undigested feed $\left(\mathrm{F}_{\text {duo,feed }}\right)$, free $\mathrm{EN}\left(\mathrm{F}_{\text {duo,end }}\right)$, and bacterial $\mathrm{N}\left(\mathrm{F}_{\text {duo,bac }}\right)$ :

$$
\mathrm{F}_{\text {duo }}=\mathrm{F}_{\text {duo,feed }}+\mathrm{F}_{\text {duo,end }}+\mathrm{F}_{\text {duo,bac }}
$$

For ${ }^{15} \mathrm{~N}$ flows:

$$
\begin{aligned}
\mathrm{E}_{\text {duo }} \times \mathrm{F}_{\text {duo }}= & \mathrm{E}_{\text {feed }} \times \mathrm{F}_{\text {duo,feed }}+\mathrm{E}_{\text {end }} \times \mathrm{F}_{\text {duo,end }} \\
& +\mathrm{E}_{\text {bac }} \times \mathrm{F}_{\text {duo,bac }}
\end{aligned}
$$

where, $\mathrm{E}_{\text {feed }}$ and $\mathrm{E}_{\mathrm{bac}}$ are the ${ }^{15} \mathrm{~N}$ enrichments of feed and bacteria, respectively. Again, the enrichment representative of the "true" precursor pool(s), $\left(\mathrm{E}_{\text {end }}\right)$, was taken to be the ${ }^{15} \mathrm{~N}$ enrichment of either the milk, duodenal mucosa, or TCA-soluble plasma fraction. Second, the bacterial $\mathrm{N}$ in the duodenal digesta $\left(\mathrm{F}_{\text {duo,bac }}\right)$ is subdivided into $\mathrm{N}$ from endogenous $\left(\mathrm{F}_{\mathrm{bac}, \text { end }}\right)$, feed $\left(\mathrm{F}_{\mathrm{bac}, \text { feed }}\right)$, and urea $\left(\mathrm{F}_{\mathrm{bac}, \text { urea }}\right)$ sources:

$$
\mathrm{F}_{\text {duo,bac }}=\mathrm{F}_{\text {bac,feed }}+\mathrm{F}_{\text {bac,end }}+\mathrm{F}_{\text {bac,urea }}
$$

Similarly, the ${ }^{15} \mathrm{~N}$ in bacteria $\left(\mathrm{E}_{\mathrm{bac}} \times \mathrm{F}_{\text {duo,bac }}\right)$ is subdivided into ${ }^{15} \mathrm{~N}$ from endogenous $\left(\mathrm{E}_{\text {end }} \times \mathrm{F}_{\text {bac,end }}\right)$, feed $\left(\mathrm{E}_{\text {feed }} \times \mathrm{F}_{\text {bac,feed }}\right)$, and urea $\left(\mathrm{E}_{\text {urea }} \times \mathrm{F}_{\mathrm{bac}, \text { urea }}\right)$ :

$$
\begin{aligned}
\mathrm{E}_{\text {bac }} \times \mathrm{F}_{\text {duo,bac }}= & \mathrm{E}_{\text {feed }} \times \mathrm{F}_{\text {bac,feed }}+\mathrm{E}_{\text {end }} \times \mathrm{F}_{\text {bac,end }} \\
& +\mathrm{E}_{\text {urea }} \times \mathrm{F}_{\text {bac,urea }}
\end{aligned}
$$

$\mathrm{E}_{\text {urea }}$ is given by urine ${ }^{15} \mathrm{~N}$ enrichment. Finally, it is assumed that a proportion $\mathrm{p}$ of bacterial $\mathrm{N}$ is derived from urea-N:

$$
\mathrm{F}_{\text {bac,urea }}=\mathrm{p} \times \mathrm{F}_{\text {duo,bac }}
$$

It is assumed that $\mathrm{p}=0.12$. This is a composite of 60 to $70 \%$ of bacterial $\mathrm{N}$ derived from $\mathrm{NH}_{3}-\mathrm{N}$ [cattle: $70 \%$, Firkins et al. (1987); 60\%, Oldick et al. (2000); sheep: $63 \%$, Koenig et al. (2000); 65\%, Siddons et al. (1985)] and 10 to $20 \%$ of $\mathrm{NH}_{3}-\mathrm{N}$ derived from urea-N [sheep: $10 \%$, Koenig et al. (2000); 11\%, Newbold et al. (2000); 11 to $32 \%$, Siddons et al. (1985)]. Calculated endogenous flows were relatively insensitive to the value for $\mathrm{p}$, e.g., a $50 \%$ error on either $\mathrm{p}$ or $\mathrm{E}_{\text {urea }}$ results in only a $12 \%$ error on endogenous flows at the duodenum. In con-

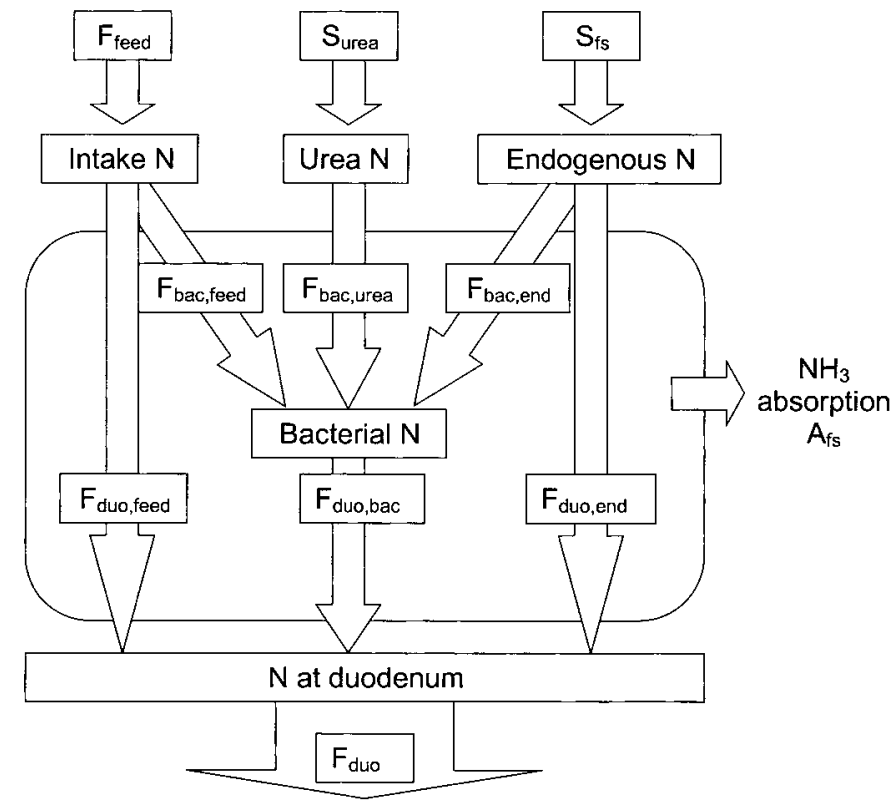

Figure 2. Forestomach model. $F_{x}$, flow of $N$ at site $x ; F_{y, x}$, flow of $\mathrm{N}$ to pool y from pool $\mathrm{x}$. Entry of $\mathrm{N}$ into the forestomachs is the summation of flow of $\mathrm{N}$ from feed $\left(\mathrm{F}_{\text {feed }}\right)$, secretion of urea $\left(\mathrm{S}_{\text {urea }}\right)$, and endogenous secretions $\left(\mathrm{S}_{\mathrm{fs}}\right)$. Flow of $\mathrm{N}$ in the duodenum $\left(\mathrm{F}_{\mathrm{duo}}\right)$ is separated into $\mathrm{N}$ derived from undigested feed $\left(\mathrm{F}_{\text {duo,feed }}\right)$, bacterial $\left(\mathrm{F}_{\text {duo,bac }}\right)$, and free endogenous $\left(\mathrm{F}_{\text {duo,end }}\right) . \mathrm{F}_{\text {duo,bac }}$ is subdivided into $\mathrm{N}$ from feed $\left(\mathrm{F}_{\mathrm{bac}, \text { feed }}\right)$, urea $\left(\mathrm{F}_{\mathrm{bac}, \text { urea }}\right)$ and endogenous secretion $\left(\mathrm{F}_{\mathrm{bac}, \text { end }}\right)$ sources. All ammonia leaving the forestomachs, other than in duodenal digesta, is defined as absorbed $\left(\mathrm{A}_{\mathrm{fs}}\right)$. 
trast, a $50 \%$ error on $\mathrm{E}_{\text {end }}$ alters duodenal endogenous flows by $100 \%$ (Zuur et al., 2001).

The measured quantities are $\mathrm{F}_{\text {duo }}, \mathrm{F}_{\text {duo,bac }}, \mathrm{E}_{\text {duo }}, \mathrm{E}_{\text {bac }}$, $\mathrm{E}_{\text {end }}, \mathrm{E}_{\text {urea }}$, and $\mathrm{E}_{\text {feed }} . \mathrm{F}_{\text {bac,urea }}$ is obtained from (9). Solving (5) through (8) simultaneously for the remaining four unknown quantities $\mathrm{F}_{\text {duo,feed }}, \mathrm{F}_{\text {duo,end }}, \mathrm{F}_{\text {bac,feed, }}$, and $\mathrm{F}_{\mathrm{bac}, \text { end }}$ gives:

$$
\begin{gathered}
F_{\text {duo,end }}=\frac{E_{\text {duo }}-E_{\text {feed }}}{E_{\text {end }}-E_{\text {feed }}} \times F_{\text {duo }}-\frac{E_{\text {bac }}-E_{\text {feed }}}{E_{\text {end }}-E_{\text {feed }}} \times F_{\text {duo,bac }} \\
F_{\text {bac,end }}=\frac{E_{\text {bac }}-}{E_{\text {end }}-}-E_{\text {feed }} \\
\times F_{\text {feed }} \\
\times p \times F_{\text {duo,bac }}-\frac{E_{\text {urea }}-E_{\text {feed }}}{E_{\text {end }}-E_{\text {feed }}} \\
F_{\text {duo,feed }}=F_{\text {duo }}-F_{\text {duo,end }}-F_{\text {duo,bac }} \\
F_{\text {bac,feed }}=F_{\text {duo,bac }}-F_{\text {bac,end }}
\end{gathered}
$$

The forestomach model, given by (5) through (9), separates urea-N secretions from endogenous protein-N secretions. Furthermore, the total EN flow at the duodenum $\left(\mathrm{F}_{\text {duo,end }}+\mathrm{F}_{\mathrm{bac} \text {,end }}\right)$ is separated into "free" EN $\left(\mathrm{F}_{\text {duo,end }}\right)$ and microbial-bound $\mathrm{EN}\left(\mathrm{F}_{\text {bac,end }}\right)$. These both exclude contributions from urea-N; instead this is given by $\mathrm{F}_{\text {bac,urea. }}$.

\section{Digestibility}

Real digestibility of $\mathrm{N}$ in the forestomachs $\left(\mathrm{d}_{\mathrm{fs}}\right)$ is given by:

$$
\mathrm{d}_{\mathrm{fs}}=\left(1-\frac{\mathrm{F}_{\text {duo,feed }}+\mathrm{F}_{\text {bac,feed }}}{\mathrm{F}_{\text {feed }}}\right) \times 100 \%
$$

where, $\mathrm{F}_{\text {feed }}$ is the measured $\mathrm{N}$ intake. Real digestibility in the intestine $\left(\mathrm{d}_{\mathrm{i}}\right)$ is defined as:

$$
\mathrm{d}_{\mathrm{i}}=\left(1-\frac{\mathrm{F}_{\text {fec,duo }}}{\mathrm{F}_{\text {duo }}}\right) \times 100 \%
$$

Real digestibility of the whole tract $\left(d_{\text {git }}\right)$ then becomes:

$$
\mathrm{d}_{\mathrm{git}}=\mathrm{d}_{\mathrm{fs}}+\left(100-\mathrm{d}_{\mathrm{fs}}\right) \times \frac{\mathrm{d}_{\mathrm{i}}}{100}
$$

Secretion and absorption. Although it is accepted that the real absorption of feed, bacterial, and EN sources will differ, for the purpose of estimation of endogenous secretion it is assumed that the mean digestibilities of these fractions are similar and, therefore, a combined value can be applied. Different combined values apply for the preduodenal and intestinal sections. Assuming that all $\mathrm{N}$ has the same digestibility in the forestomachs, secretion of urea-N $\left(\mathrm{S}_{\text {urea }}\right)$ and $\mathrm{EN}$ $\left(\mathrm{S}_{\mathrm{fs}}\right)$ into the forestomachs are given by:

$$
\begin{gathered}
\mathrm{S}_{\text {urea }}=\frac{\mathrm{F}_{\text {bac,urea }}}{100-\mathrm{d}_{\mathrm{fs}}} \times 100 \\
\mathrm{~S}_{\mathrm{fs}}=\frac{\mathrm{F}_{\text {duo,end }}+\mathrm{F}_{\text {bac,end }}}{100-\mathrm{d}_{\mathrm{fs}}} \times 100
\end{gathered}
$$

Absorption of $\mathrm{N}$ in the forestomachs $\left(\mathrm{A}_{\mathrm{fs}}\right)$ then becomes:

$$
\mathrm{A}_{\mathrm{fs}}=\frac{\mathrm{d}_{\mathrm{fs}}}{100} \times\left(\mathrm{S}_{\mathrm{fs}}+\mathrm{S}_{\text {urea }}+\mathrm{F}_{\text {feed }}\right)
$$

Similarly, assuming that digestibility of EN secretions into the intestine is the same as for duodenal digesta-N, then total EN secretions into the intestine $\left(\mathrm{S}_{\mathrm{i}}\right)$ and total absorption of $\mathrm{N}$ in the intestine $\left(\mathrm{A}_{\mathrm{i}}\right)$ are given by:

$$
\begin{gathered}
\mathrm{S}_{\mathrm{i}}=\frac{\mathrm{F}_{\text {fec,end }}}{100-\mathrm{d}_{\mathrm{i}}} \times 100 \\
\mathrm{~A}_{\mathrm{i}}=\frac{\mathrm{d}_{\mathrm{i}}}{100} \times\left(\mathrm{S}_{\mathrm{i}}+\mathrm{F}_{\text {duo }}\right)
\end{gathered}
$$

$\mathrm{S}_{\text {urea }}, \mathrm{S}_{\mathrm{fs}}, \mathrm{S}_{\mathrm{i}}, \mathrm{A}_{\mathrm{fs}}$ and $\mathrm{A}_{\mathrm{i}}$ are all in $\mathrm{g} \mathrm{N} / \mathrm{d}$.

The calculations described above were applied to each cow and each diet in turn, using the average enrichments and flows which were calculated as the mean of d 23 and 24 .

\section{Statistical Analysis}

All statistical analyses were based on ANOVA, using the GLM procedure of SAS (1996). The quantities obtained from the model calculations were analyzed by ANOVA, with terms included for animal and diet (compared with a period within animal term). The enrichment data were tested for a day effect as follows. For each sample site, the enrichments for $\mathrm{d} 23$ and 24 were analyzed by ANOVA, with terms included for animal, diet (compared with a period within animal term), day, and diet-by-day interaction (compared with an observation within period within animal term). Differences in enrichment between precursor pools, based on the average enrichments of $\mathrm{d} 23$ and 24, were tested by ANOVA, with terms included for animal, diet (compared with a period within animal term), precursor pool, and dietby-precursor pool interaction (compared with an observation within period within animal term). The Bonfer- 
Table 2. Dry matter intake and diet digestibility of cows fed low (LF) or high fiber (HF) diets. ${ }^{1}$

\begin{tabular}{lllll}
\hline & \multicolumn{3}{c}{ Diets } & \\
\cline { 2 - 3 } Parameter & HF & LF & SEM & $P^{2}$ \\
\hline DM intake $^{3}(\mathrm{~kg} / \mathrm{d})$ & 14.2 & 14.2 & 0.30 & NS \\
Apparent digestibility (\%) & & & & \\
DM & 71.6 & 72.7 & 0.24 & NS \\
Energy & 71.4 & 72.1 & 0.32 & NS \\
NDF & 66.9 & 53.5 & 0.71 & 0.04 \\
ADF & 64.0 & 46.1 & 0.89 & 0.04 \\
\hline
\end{tabular}

${ }^{1}$ Least square means (HF, $\mathrm{n}=3 ; \mathrm{LF}, \mathrm{n}=4$ ) and SEM given for $\mathrm{n}$ $=3$.

${ }^{2} \mathrm{NS}$, not significant, $P>0.10$.

${ }^{3}$ Intake measured during the total collection period.

roni test was used to identify significant differences between the means. There was no significant effect of period, and this was excluded from the analyses. $P$ values $<0.05$ are regarded as significant, and $P$-values $<0.10$ are regarded as a trend.

\section{RESULTS}

Data from the cow fitted with the duodenal and ileal cannula were discarded for the first period, (HF treatment) because the ileal cannula blocked on $d 23$, therefore, affecting voluntary intake on d 24 .

There was no treatment effect on milk production $(16.9 \mathrm{~kg} / \mathrm{d} \pm 0.9 \mathrm{SEM})$, milk fat $(4.01 \% \pm 0.11 \mathrm{SEM})$, milk protein $(3.48 \% \pm 0.13 \mathrm{SEM})$, milk lactose $(4.46 \%$ $\pm 0.04 \mathrm{SEM})$ and milk urea-N $(11.8 \mathrm{mM} \pm 0.6 \mathrm{SEM})$ concentrations.

As planned, the diets were isonitrogenous, but differed $(P<0.01)$ in fiber content (Table 1$)$. Dry matter intake was similar between treatment $(14.2 \mathrm{~kg} \mathrm{DM} / \mathrm{d}$; Table 2), but NDF intake was different (5.4 and $3.4 \pm$ $0.1 \mathrm{~kg} / \mathrm{d}$ for $\mathrm{HF}$ and LF, respectively; $P<0.01$ ). Nitrogen intake was similar between treatments and averaged $394 \mathrm{~g} \mathrm{~N} / \mathrm{d}$. Apparent digestibilities of DM and N were not affected by the treatments, but digestibility of the fiber fractions (NDF and ADF) were higher $(P=0.04)$ with the HF than the LF diet (Table 2; also see Table 4).

The average enrichment of samples collected on $d 23$ and 24 from various biological tissues is presented in Table 3. Enrichments on d 24 exceeded $(P<0.001)$ those on d 23 by between 3\% (plasma), 8 to $9 \%$ (duodenal digesta, bacteria, and mucosa), and $10 \%$ (urine and feces). The enrichment was markedly different $(P<$ 0.001) between the various precursor pools, with milk being the highest, followed by intestinal mucosa, TCAsoluble plasma fraction, and urine. Overall, fiber treatment had no effect on enrichment of the precursor pools, and there was no treatment by precursor pool interaction.
Table 3. Effect of dietary fiber on the enrichment (atom percent) of different potential precursor pools on the last $2 \mathrm{~d}$ of a 200 -h infusion of $\left[{ }^{15} \mathrm{~N}\right]$-leucine in cows fed low (LF) or high fiber (HF) diets. ${ }^{1}$

\begin{tabular}{lllll}
\hline & \multicolumn{3}{c}{ Diets } & \\
\cline { 2 - 3 } Precursor Pool & HF & LF & SEM & $P^{2}$ \\
\hline Milk & 0.42490 & 0.42593 & 0.00015 & NS \\
Intestinal mucosa & 0.41003 & 0.40762 & 0.00123 & NS \\
Plasma-TCA & 0.39830 & 0.38901 & 0.01044 & NS \\
Urine & 0.38171 & 0.37911 & 0.00082 & NS \\
\hline
\end{tabular}

${ }^{1}$ Least squares means presented with SEM for $\mathrm{n}=3$.

${ }^{2} \mathrm{NS}$, not significant, $P>0.10$.

For the combined data tested by analysis of variance, there was no significant effect of diet or diet by tissue interaction, but the tissue effect was significant $(P<0.001)$. The Bonferroni test indicated all tissues were significantly different from each other.

Values estimated from the model varied in magnitude, depending on the selected precursor pool (Table 4). In practice, however, differences and trends between treatments remained similar regardless of precursor pool selected (Table 4). As will be discussed later, mucosa enrichment was chosen as the most representative, and all subsequent data are based upon this parameter. Feed $\mathrm{N}$ escaping rumen degradation was greater $(P=$ 0.004) in the HF diet compared with the LF diet (Table 4). In contrast, the bacterial $\mathrm{N}$ flow at the duodenum tended to be lower $(P=0.06)$ with the HF diet. This was due mainly to a decreased $(P<0.05)$ contribution of microbial protein from feed origin, although microbial protein from urea-N also tended $(P=0.06)$ to decrease in cows fed the HF diet (Table 4). The total EN fraction at the duodenum level was not affected by treatments, neither in absolute nor relative terms (Table 5). This fraction contained similar proportions of secretions that were free or incorporated into microbial protein, and these proportions were not affected by treatments either (Table 5). Total EN loss in the feces was not affected by the diet $(P<0.10)$, but proportion from fecal $\mathrm{N}$ from endogenous origin increased $(P=0.03)$ with the LF diet. Also, there was a trend $(P=0.10)$ for higher fecal loss from endogenous secretions into the small intestine with the LF diet (Table 5).

Based on EN losses and estimated rate of digestion, total endogenous secretions were estimated (Table 6). Although endogenous secretions in the rumen were not affected by the diets, estimated urea-N recycled into the rumen increased $(P=0.01)$ with the LF diet. Estimated endogenous secretion into the small intestine also tended $(P=0.09)$ to be greater for the LF diet. Total absorption (diet, bacterial, and endogenous) from the small intestine was also greater $(P=0.05)$ in the $\mathrm{LF}$ group. The real digestibility of $\mathrm{N}$ in the rumen ranged between 15 and $21 \%$. The computed real digestibility 
Table 4. Flows of $\mathrm{N}(\mathrm{g} / \mathrm{d})$ across the digestive tract in cows fed low (LF) or high fiber (HF) diets based on either mucosa, milk, or TCAsoluble plasma fraction enrichment as representative of the precursor pool. ${ }^{1}$

\begin{tabular}{|c|c|c|c|c|c|c|c|c|c|c|c|c|}
\hline \multirow[b]{2}{*}{ Parameters $^{2}$} & \multicolumn{4}{|c|}{ Mucosa } & \multicolumn{4}{|c|}{ Milk } & \multicolumn{4}{|c|}{ Plasma } \\
\hline & $\mathrm{HF}$ & $\mathrm{LF}$ & SEM & $P^{3}$ & $\mathrm{HF}$ & $\mathrm{LF}$ & SEM & $P$ & $\mathrm{HF}$ & $\mathrm{LF}$ & SEM & $P$ \\
\hline atake $\left(\mathrm{F}_{\text {feed }}\right)$ & 387 & 401 & 13.9 & NS & 387 & 401 & 13.9 & $\mathrm{NS}$ & 387 & 401 & 13.9 & NS \\
\hline Duodenal digesta $\left(\mathrm{F}_{\text {duo }}\right)$ & 398 & 446 & 16.6 & NS & 398 & 446 & 16.6 & NS & 398 & 446 & 16.6 & NS \\
\hline Undigested feed $\left(\mathrm{F}_{\text {duo,feed }}\right)$ & 85 & 67 & 2.7 & 0.04 & 94 & 78 & 3.7 & 0.10 & 60 & 39 & 3.5 & 0.05 \\
\hline Free endogenous $\mathrm{N}\left(\mathrm{F}_{\text {duo,end }}\right)$ & 31 & 34 & 3.7 & NS & 23 & 23 & 2.7 & $\mathrm{NS}$ & 56 & 62 & 8.6 & NS \\
\hline Bacterial N ( $\left.\mathrm{F}_{\text {duo,bac }}\right)$ & 282 & 345 & 11.7 & 0.06 & 282 & 345 & 11.7 & 0.06 & 282 & 345 & 11.7 & 0.06 \\
\hline From feed $\left(\mathrm{F}_{\text {bac,feed }}\right)$ & 219 & 271 & 8.2 & 0.05 & 227 & 282 & 8.7 & 0.05 & 196 & 244 & 3.5 & 0.01 \\
\hline From endogenous $\mathrm{N}$ ( $\left.\mathrm{F}_{\mathrm{bac}, \text { end }}\right)$ & 29 & 32 & 2.5 & NS & 21 & 22 & 1.9 & NS & 52 & 60 & 7.0 & NS \\
\hline From urea-N ( $\left.\mathrm{F}_{\text {bac,urea }}\right)$ & 34 & 41 & 1.4 & 0.06 & 34 & 41 & 1.4 & 0.07 & 34 & 41 & 1.4 & 0.07 \\
\hline Feces $\left(F_{\text {fec }}\right)$ & 139 & 136 & 7.9 & NS & 139 & 136 & 7.9 & NS & 139 & 136 & 7.9 & NS \\
\hline Undigested duodenal digesta $\left(\mathrm{F}_{\mathrm{fe}}\right.$ & 134 & 127 & 8.9 & NS & 135 & 130 & 8.5 & NS & 128 & 115 & 10.0 & NS \\
\hline Endogenous $\mathrm{N}$ from secretions into intestine $\left(\mathrm{F}_{\text {fec,end }}\right)$ & 5 & 9 & 1.1 & 0.10 & 4 & 6 & 0.6 & NS & 11 & 21 & 2.1 & 0.08 \\
\hline
\end{tabular}

${ }^{1}$ Least squares means. SEM based on $\mathrm{n}=3$.

${ }^{2}$ Based on the model described on pages 10 to 13 and Figures 1 and 2. Model variables are given between parentheses.

${ }^{3} \mathrm{NS}$, not significant, $P>0.10$.

of $\mathrm{N}$ across the small intestine was $69 \%$ and averaged $75 \%$ across the whole tract.

\section{DISCUSSION}

A number of technical and theoretical issues are fundamental to kinetic measurement of endogenous losses and subsequent data interpretation. The first relates to choice of tracer amino acid(s) which, ideally, should be distributed uniformly (or at least widely) between the various secreted proteins. A number of approaches have been used, including use of mixed $\left[{ }^{15} \mathrm{~N}\right]$ protein sources (Krawielitzki and Timm, 1978) or use of single amino acid labels (e.g., $\left[{ }^{13} \mathrm{C}\right]$ leucine; Zuur et al., 2001). A common technique is to use a $\left[{ }^{15} \mathrm{~N}\right]$ amino acid as a transamination source to label a variety of other amino acids and, thus, act as a form of universal tracer. While many studies on protein dynamics have used $\left[{ }^{15} \mathrm{~N}\right]$ glycine, label transfer is restricted to nonessential amino acids (Matthews et al., 1981). A more balanced ${ }^{15} \mathrm{~N}$ distribution between essential and nonessential amino acids has been shown in pigs using $\left[{ }^{15} \mathrm{~N}\right]$ leucine (de Lange et al., 1992; Hess et al., 1998), and this is aided by the occurrence of leucine transaminase activity in most tissues and organs in both nonruminants and ruminants (Papet et al., 1988). Calculations can be based on either $\left[{ }^{15} \mathrm{~N}\right] l$ leucine kinetics (de Lange et al., 1992) or the mixed ${ }^{15} \mathrm{~N}$ fraction (Huisman et al., 1992). The latter approach was adopted in the current study.

For large species, such as the dairy cow, with relatively slow turnover rates, tissues will not be labeled to 'plateau' even after the $8 \mathrm{~d}$ of infusion. This was confirmed by the differences in enrichment between $d$ 23 and 24 for most samples analyzed. Such differences do not have a major impact on the model, however, provided the time of passage between sample sites is relatively short. For example, sensitivity analysis showed that a 12-h interval between secretion of endogenous protein into the rumen and appearance at the duodenum would introduce an error of less than $3 \%$ on

Table 5. Further breakdown of net endogenous losses across sections of the digestive tract of dairy cows fed low (LF) or high fiber (HF) diets based on mucosa enrichment as representative of the precursor pool. ${ }^{1}$

\begin{tabular}{lrrrl}
\hline Parameters $^{2}$ & HF & LF & SEM & $P^{3}$ \\
\hline Total endogenous N in duodenal digesta, g N/d & 60 & 66 & 6.1 & NS \\
Free endogenous N from secretions into forestomachs $\left(F_{\text {duo,end }}\right.$, g N/d) & 31 & 34 & 3.7 & NS \\
Endogenous N in bacteria $\left(F_{\text {bac,end }}, \mathrm{g}\right.$ N/d) & 29 & 32 & 2.5 & NS \\
Duodenal N from endogenous origin $(\%)$ & 15 & 15 & 0.8 & NS \\
Total endogenous N in feces, g N/d & 25 & 28 & 1.5 & NS \\
From endogenous secretions into intestine $\left(F_{\text {fec,end, }}\right.$, g N/d) & 5 & 9 & 1.1 & 0.10 \\
From endogenous secretions into forestomachs, g N/d & 20 & 19 & 2.4 & NS \\
Fecal N from endogenous origin $(\%)$ & 18 & 20 & 0.3 & 0.03 \\
\hline
\end{tabular}

\footnotetext{
${ }^{1}$ Least squares means. SEM based on $\mathrm{n}=3$.

${ }^{2}$ Based on the model described on pages 10 to 13 and Figures 1 and 2. Model variables are given between parentheses. ${ }^{1}$

${ }^{3} \mathrm{NS}$, not significant, $P>0.10$.
} 
Table 6. Secretions, absorptions, and digestibilities of $\mathrm{N}$ across sections of the digestive tract of dairy cows fed low (LF) or high fiber (HF) diets based on mucosa enrichment as representative of the precursor pool. ${ }^{1}$

\begin{tabular}{lrrrl}
\hline Parameters $^{2}$ & HF & LF & SEM & $P^{3}$ \\
\hline Secretions, g N/d & & & & \\
Urea-N into forestomachs $\left(\mathrm{S}_{\mathrm{urea}}\right)$ & 43 & 49 & 1.4 & 0.01 \\
Endogenous N into forestomachs $\left(\mathrm{S}_{\mathrm{fs}}\right)$ & 78 & 78 & 3.8 & $\mathrm{NS}$ \\
Endogenous N into intestine $\left(\mathrm{S}_{\mathrm{i}}\right)$ & 14 & 32 & 3.8 & 0.09 \\
Absorption, g N/d & & & & \\
$\quad$ Forestomachs $\left(\mathrm{A}_{\mathrm{fs}}\right)$ & 110 & 82 & 31.5 & $\mathrm{NS}$ \\
$\quad$ Intestine $\left(\mathrm{A}_{\mathrm{i}}\right)$ & 274 & 341 & 10.3 & 0.05 \\
Real digestibility, \% & & & & \\
Forestomachs $\left(\mathrm{d}_{\mathrm{fs}}\right)$ & 21 & 15 & 5.2 & $\mathrm{NS}$ \\
Intestine $\left(\mathrm{d}_{\mathrm{i}}\right)$ & 66 & 71 & 1.7 & $\mathrm{NS}$ \\
Whole tract $\left(\mathrm{d}_{\mathrm{git}}\right)$ & 74 & 76 & 2.2 & $\mathrm{NS}$ \\
\hline
\end{tabular}

${ }^{1}$ Least squares means. SEM based on $\mathrm{n}=3$.

${ }^{2}$ Based on the model described on pages 10 to 13 and Figures 1 and 2. Model variables are given between parentheses.

${ }^{3} \mathrm{NS}$, not significant, $P<0.10$.

estimates of endogenous flow. For a 24-h interval, the error increases to $7 \%$. Similar sensitivity analysis related to errors in measured bacterial-N flow from the forestomachs showed that a $10 \%$ underestimate would result in a less than $2 \%$ overestimate of total endogenous flow at the duodenum.

\section{Precursor Pool}

Several studies with ruminants and nonruminants (Tamminga et al., 1995; Leterme et al., 1996; Nyachoti et al., 1997) have shown that the main limitation to the estimation of endogenous protein losses, following continuous infusion of isotopic tracers, is the adequacy of the precursor pool chosen as representative of site(s) of endogenous protein production. The TCA-soluble fraction of plasma has been often used, as this offers ease of access. Unfortunatly, as de Lange et al. (1992) indicated, this will lead to overestimates of endogenous secretion because of the presence of metabolites other than amino acids. In dairy cows, for example, average plasma amino acid-N concentration is $1.8 \mathrm{mM}$, while urea-N and ammonia- $\mathrm{N}$ concentrations would be approximately 10 and $0.15 \mathrm{mM}$, respectively (Lapierre and Lobley, 2001). As the latter two are both derived primarily from unlabeled feed sources, they will mask the enrichment of amino acids in the TCA-soluble plasma (Tamminga et al., 1995). As an alternative, Lien et al. (1997) and Yu et al. (2000) proposed the use of the plasma enrichment of the infused AA (e.g., leucine), rather than total $\mathrm{N}$, to estimate $\mathrm{EN}$ flows and losses.

In the present study, various pools were examined. The TCA-soluble plasma was chosen because of its universal use and compared with milk, duodenal mucosa, and urine. In dairy animals, milk samples are easily accessible and should give a good representation of rapid turnover-secretory tissues, such as pancreas (Attaix et al., 1994) and gut mucosa (Lobley et al., 1994). Intestinal mucosa was also sampled here because of both the known direct contribution to endogenous secretions (e.g., desquamation, goblet cell products) and the anatomical closeness to other secretory tissues (e.g., pancreas). In practice, milk yielded the highest enrichment, and this resulted in the lowest estimate for EN flows and losses. Intestinal mucosa yielded slightly lower values, probably due to dilution from feed-derived amino acid inflow and the presence of nucleic acids. In the rumen model, the enrichment of the rumen mucosa protein was assumed to be similar to intestinal mucosa. Although the half-life of the rumen mucosa (2 to $3 \mathrm{~d}$ ) is longer than that of the small intestine ( 1 to $1.5 \mathrm{~d}$; Lobley et al., 1994), protein labeling in both at the end of $8 \mathrm{~d}$ of isotope infusion should be similar, especially as the intestinal mucosa will be slightly diluted by feedderived amino acids. The TCA-soluble plasma enrichment was substantially lower than those of milk and mucosa, for reasons discussed above. Urine enrichment was lower than for TCA-soluble plasma, contrary to observations reported in pigs (Souffrant et al., 1982; de Lange et al., 1990), but up to $70 \%$ of the urinary urea, which contributes 60 to $80 \%$ to total urine N, in ruminants is synthesized from feed-derived rumen ammonia (Lapierre and Lobley, 2001). This contrasts with nonruminants where tissue amino acids are the major ureagenic precursor. In consequence, the enrichment of urine was used only for the estimation of urea $-{ }^{15} \mathrm{~N}$ reentering the gut.

Although estimations of endogenous $\mathrm{N}$ losses differed in magnitude (by up to threefold) based on the various pools, similar trends between treatments were observed independently of the chosen precursor (see later). Nonetheless, for the anatomical and metabolic reasons described above, the subsequent discussion is based on duodenal mucosal providing enrichments representative of the "true" precursors for both forestomach and intestinal endogenous secretions.

\section{Estimations of the Different Fractions of Endogenous N Flows}

In ruminants, recirculation of ${ }^{15} \mathrm{~N}$-labeled protein into the lumen of the digestive tract is derived not only from endogenous protein sources (as in nonruminants), but also from urea- $\mathrm{N}$ that reentered the gut, is hydrolyzed to ammonia, and then incorporated into microbial protein. This latter incorporation occurs mainly in the rumen and represents a salvage mechanism for $\mathrm{N}$. While this might be considered as an endogenous source (Leng and Nolan, 1984), the impact on net amino acid 
use differs from the losses associated with protein secreted by gut tissues (Lapierre and Lobley, 2001). Furthermore, not all of the endogenous secretions into the rumen will arrive at the duodenum unchanged, but rather some will have been incorporated into the microbial biomass. Therefore, a model was developed to separate preduodenal and intestinal compartments for ${ }^{15} \mathrm{~N}$ inflows, with allowance for inflows from urea-N and for incorporation of endogenous secretions into microbial proteins. For the purposes of discussion, EN flows relate only to those derived from $\mathrm{N}$ sources other than urea.

Endogenous $\mathrm{N}$ flows at the duodenum estimated by adding free $\mathrm{EN}\left(\mathrm{F}_{\text {duo,end }}\right)$ and bacterial derived from $\mathrm{EN}$ $\left(\mathrm{F}_{\text {bac,end }}\right)$ using mucosa precursor pool averaged $63 \mathrm{~g} / \mathrm{d}$ : This represents $15 \%$ of duodenal $\mathrm{N}$ flow or $4.4 \mathrm{~g} \mathrm{~N}$ per $\mathrm{kg}$ DMI. This is higher than the $1.9 \mathrm{~g} / \mathrm{kg}$ DMI used in the NRC (2001); however, this latter value was based on studies where methodologies excluded any EN incorporated in microbial-N, i.e., only the "free" endogenous contribution to the duodenal $\mathrm{N}$ flow is estimated with the NRC (2001). In the current study, such 'free' endogenous flows to the duodenum also averaged $2.3 \mathrm{~g} \mathrm{~N} / \mathrm{kg}$ DMI, similar to the value used by NRC (2001). Nonetheless, these values underestimate total endogenous flow, as they do not account for the substantial use of EN to support microbial protein synthesis. Indeed, in the current study the amount of microbial-N derived from endogenous secretions into the rumen was similar to that predicted from urea-N sources. This substantial incorporation of EN into the microbial biomass needs to be considered in future ration formulation schemes, particularly when differences may exist in amino acid composition between the substrate (endogenous) and product (microbial) proteins.

Estimated rumen absorption of $\mathrm{N}$ from mucosa precursor pool values averaged $96 \mathrm{~g} / \mathrm{d}(286 \mathrm{mmol} / \mathrm{h})$; this was probably as ammonia and would represent approximately $60 \%$ of reported total portal ammonia absorption (average, $411 \mathrm{mmol} / \mathrm{h}$ ) in cows with similar DM and $\mathrm{N}$ intake (McGuire et al. 1989; De Visser et al., 1997). Ammonia, however, is also absorbed from nonrumen tissues in the digestive tract (Gate et al., 1999; Lapierre and Lobley, 2001).

Fecal $\mathrm{N}$ from endogenous origin contributed to $19 \%$. The value for metabolic fecal output of the NRC (2001), $4.8 \mathrm{~g} \mathrm{~N} / \mathrm{kg} \mathrm{DMI}$, would yield a contribution of undigested endogenous secretions of $50 \%$ of fecal output. This value was estimated using two approaches, with both techniques yielding values in the same range ( 4.7 to $5.4 \mathrm{~g} \mathrm{~N} / \mathrm{kg} \mathrm{DMI})$. The technique used for dairy cows was to feed diets of different CP content and then regress intake of digestible $\mathrm{CP}$ on intake of $\mathrm{CP}$, with the intercept estimated as metabolic fecal protein (Boekholt, 1976; Waldo and Glenn, 1984). Van Bruchem et al. (1997) also reported a contribution of 50\% of endogenous losses to fecal output, based on ${ }^{15} \mathrm{~N}$ studies. The lower value obtained in the present study can be explained by two factors. First, for the techniques reported in NRC (2001) and used by Van Bruchem (1997; classical ${ }^{15} \mathrm{~N}$ infusion), protein endogenous losses include urea that reentered the gut and were used as a source of $\mathrm{N}$ for microbial protein synthesis. This fraction was assessed separately in our model. Second, the values reported by Van Bruchem (1997) were based on the plasma TCA-soluble plasma as representative of the precursor pool. Using the TCA-soluble plasma in our model more than doubled (to $36 \%$; data not presented) the estimated contribution of endogenous loss to fecal output. Similarly, when infusing ${ }^{15} \mathrm{~N}$-leucine, using the enrichment of plasma leucine, rather than the enrichment of the TCA-soluble plasma, decreased the contribution of endogenous loss to ileal $\mathrm{N}$ flow, from 28 to $9 \%$ (de Lange et al., 1992). For the reasons discussed above, the mucosa or milk are proposed as more representative of the precursor pool for endogenous secretions and, therefore, the current predicted contributions are probably more correct than those used by Van Bruchem (1989, 1997).

Most of endogenous losses in the feces, $74 \%$, originated from nonabsorbed rumen endogenous flows, with only $26 \%$ from secretions related to small intestine metabolism. Although these net endogenous losses from the small intestine appear small, the total secretion into the lumen is appreciable. For example, every $10 \mathrm{~g}$ of EN excreted in feces would arise from $202 \mathrm{~g}$ protein secretions (10 g N $\times 6.25 \%$, at $69 \%$ digestibility for amino acids). Thus, across the two intakes, the $26 \mathrm{~g}$ of EN lost would arise from $524 \mathrm{~g}$ of protein secretions, equivalent to $30 \%$ of the protein synthesized across the portal-drained viscera of dairy cows (Lapierre et al., 2002). Real digestibility of $\mathrm{N}$ across the small intestine (69\%) was slightly lower than estimations of 75 to $80 \%$ suggested by Van Bruchem et al. (1989) and for microbial crude protein by Storm et al. (1983).

\section{Effect of Fiber}

To balance the diets, ground barley was substituted for soybean hulls, ingredients that have similar crude protein and energy but different fiber contents. Soybean hulls have been suggested as a good ingredient to enhance the fiber content of diets without reducing digestible energy (Nakamura and Owen, 1989) and CP (Sarwar et al., 1991).

Dry matter digestibility was not affected by the fiber content of the diets. Previous experiments have shown either no effect (Bernard and McNeill, 1991), an increase (Weidner and Grant, 1994), or a decrease (Edi- 
onwe and Owen, 1989; Nakamura and Owen, 1989) in DM digestibility when soybean hulls are included in the diet of lactating cows. Factors such as the ingredients used or the level of DM intake may influence digestibility.

Apparent digestibilities of NDF and ADF were higher for the HF than for the LF diet. Several studies have shown that the addition of soybean hulls to the diet reduces ruminal fiber digestion, but this decrease may be compensated by higher digestibility in the hindgut (Nakamura and Owen, 1989; Grant, 1997). On the other hand, Edionwe and Owen (1989) observed an increase in NDF and ADF digestibilities when soybean hulls were substituted for oats and corn in diets of lactating cows fed ad libitum. A similar increase in fiber digestibility has been reported by Weidner and Grant (1994) when soybean hulls were included in a diet based on alfalfa and corn silage. The increase in fiber digestibility could be partially explained by the high ruminal digestibility of soybean hulls (Edionwe and Owen, 1989; Nakamura and Owen, 1989; Weidner and Grant, 1994) or by a decrease in the rate of passage (Grant, 1997).

In the present experiment, the microbial $\mathrm{N}$ flow into the duodenum was $18 \%$ lower when cows were offered the HF diet compared with those fed the LF diet. Inclusion of soybean hulls decreased rapidly-digestible carbohydrates; this relates directly to microbial protein synthesis (NRC, 2001). Inclusion of soybean hulls rather than ground barley to formulate isonitrogenous diets did not affect either real or apparent $\mathrm{N}$ digestibility. Although the source of fiber influences the abrasive actions that enhance epithelial cellular desquamation (Tamminga et al., 1995) this can be compensated by a greater capture of ammonia arising from urea hydrolysis by the rumen microbes. While barley and soybean hulls have similar energy content, the type of energy is different. Barley contains starch that is rapidly fermented in the rumen and aids capture of $\mathrm{N}$ (including of endogenous origin) for microbial growth. This was shown in the increase of duodenal $\mathrm{N}$ flow with the LF diet. Future work on endogenous secretions within the rumen must include more direct measurements of urea utilization (rather than the fixed factor used in the current study) in order to resolve the fates of various EN secretions more precisely.

Fecal appearance of EN losses from small intestine secretions was similar between diets. This contrasts with observations in nonruminants, usually based on losses at the terminal ileum, where additional fiber increases losses (Sauer et al., 1977; Schulze et al., 1994, 1995). This may be compensated with the LF diet through increases in secretion of enzymes to digest the extra bacteria flow.

\section{CONCLUSIONS}

This study demonstrates that dietary fiber level has a relatively small influence on the net endogenous losses of lactating dairy cows. Estimated endogenous secretions and losses using the isotopic dilution technique varied markedly according to the precursor pool chosen, although the qualitative comparisons between treatments were similar. If determinations of absolute endogenous flows or net losses are required, the intestinal mucosa, or milk for lactating animals, appears a better choice of precursor pool. The mathematical model developed provides a first basis to describe the contribution of ruminal metabolism to endogenous secretion in dairy cows. In particular, it allows for separation of endogenous inputs between urea and other $\mathrm{N}$ sources and how these are partitioned amongst rumen outflow products, secretions into the small intestine, and loss in the feces. Total endogenous flows to the duodenum were twice the anabolic $\mathrm{N}$ inputs from urea and need to be accounted in future prediction models. Endogenous secretions into the small intestine may contribute $30 \%$ towards total protein turnover across the digestive tract and, thus, represent a major contribution to both the $\mathrm{N}$ and energy economy of lactating animals.

\section{ACKNOWLEDGMENTS}

The authors thank M. Pelletier, D. Bournival, and M. Léonard for technical assistance. They also thank K. Carter and the dairy barn staff for taking care of the cows. We are grateful to Dairy Farmers of Canada, Agriculture and Agri-Food Canada, and Université Laval for funding this work.

\section{REFERENCES}

Attaix, D., D. Taillandier, S. Temparis, D. Larbaud, E. Aurousseau, L. Combaret, and L. Voisin. 1994. Regulation of ATP-ubiquitindependent proteolysis in muscle wasting. Reprod. Nutr. Dev. 34:583-597.

Barcells, J., J. A. Guada, J. M. Peiro, and D. S. Parker. 1992. Simultaneous determination of allantoin and oxypurines in biological fluids by high-performance liquid chromatography. J. Chromato. 575:153-157.

Bartelt, J., W. Drochner, K.-P. Götz, J. Szakacz, Z. Čerešňáková, and A. Sommer. 1999. Determination of endogenous nitrogen associated with bacteria in ileal digesta of pigs receiving cerealbased diets with or without fish meal and various fiber supplements by using a simple ${ }^{15} \mathrm{~N}$-dilution technique. J. Anim. Feed Sci. 8:425-440.

Bernard, J. K., and W. W. McNeill. 1991. Effect of high-fiber energy supplements on nutrient digestibility and milk production of lactating dairy cows. J. Dairy Sci. 74:991-995.

Berthiaume, R., P. Dubreuil, M. Stevenson, B. W. McBride, and H. Lapierre. 2001. Intestinal disappearance, mesenteric and portal appearance of amino acids in dairy cows fed ruminally protected methionine. J. Dairy Sci. 84:194-203.

Boekholt, H. A. 1976. Nitrogen metabolism of the lactating cow and the role of gluconeogenesis from amino acids. Meded. Landbouwhogesch. Wageningen 76:10. 
Bondi, A. A. 1987. Animal Nutrition. Wiley-Interscience Publication. $540 \mathrm{pp}$.

Canadian Council of Animal Care. 1993. Guide to the care and use of experimental animals. Vol. 1, 2nd ed. E. D. Olfert, B. M. Cross, and A. A. McWilliam, eds. CCAC, Ottawa. Ontario, Canada.

Chen, X. B., and M. J. Gomez. 1992. Estimation of microbial protein supply to sheep and cattle based on urinary excretion of purine derivatives - an overview of the technical details. International feed resources unit, RRI, Aberdeen, Occasional Publication.

de Lange, C. F. M, W. B. Souffrant, and W. C. Sauer. 1990. Real ileal protein and amino acid digestibilities in feedstuffs for growing pigs as determined with the ${ }^{15} \mathrm{~N}$-isotope dilution technique. J. Anim. Sci. 68:409-418.

de Lange, C. F. M., W. C. Sauer, W. B. Souffrant, and K. A. Lien. 1992. ${ }^{15} \mathrm{~N}$-Leucine and ${ }^{15} \mathrm{~N}$-Isoleucine isotope dilution techniques versus the ${ }^{15} \mathrm{~N}$-isotope dilution technique for determining the recovery of endogenous protein and amino acids in digesta collected from the distal ileum in pigs. J. Anim. Sci. 70:1848-1856.

de Visser, H., H. Valk, A. Klop, J. Van der Meulen, J. G. M. Bakker, and G. B. Huntington. 1997. Nutrient fluxes in splanchnic tissue of dairy cows: Influence of grass quality. J. Dairy Sci. 80:16661673 .

Edionwe, A. O., and F. G. Owen. 1989. Relation of intake to digestibility of diets containing soyhulls and distillers dried grains. J. Dairy Sci. 72:1786-1792.

Fenton, T. W., and M. Fenton. 1979. An improved procedure for the determination of chromic oxide in feed and feces. Can. J. Anim. Sci. 59:631-634.

Firkins, J. L., L. L. Berger, N. R. Merci, G. C. Fahey, Jr., and R. L. Mulva. 1987. Ruminal nitrogen metabolism in steers as affected by feed intake and dietary urea concentration. J. Dairy Sci. 70:2302-2311.

Gate, J. J., D. S. Parker, and G. E. Lobley. 1999. The metabolic fate of the amino-N group of glutamine in the tissues of the gastrointestinal tract in $24-\mathrm{h}$ fasted sheep. Br. J. Nutr. 81:297-306.

Grant, R. J. 1997. Interactions among forages and nonforage fiber sources. J. Dairy Sci. 80:1438-1446.

Hess, V., J. N. Thibault, and B. Seve. 1988. The ${ }^{15} \mathrm{~N}$ amino acid dilution method allows the determination of the real digestibility and of the ileal endogenous losses of the respective amino acid in pigs. J. Nutr. 128:1969-1977.

Huisman, J., T. Heinz, A. F. Van der Poel, P. Van Leeuwen, W. B. Souffrant, and M. W. Verstegen. 1992. True protein digestibility and amounts of endogenous protein measured with the ${ }^{15} \mathrm{~N}$-dilution technique in piglets fed on peas (Pisum sativum) and common beans (Phaseolus vulgaris). Br. J. Nutr. 68:101-110.

Koenig, K. K., C. J. Newbold, F. M. McIntosh, and L. M. Rode. 2000. Effect of protozoa on bacterial nitrogen recycling in the rumen. J. Anim. Sci. 78:2431-2445.

Krawielitzki, K., and E. Timm. 1978. Tracer studies in rats with ${ }^{15} \mathrm{~N}$ labeled wheat for the determination of endogenous and exogenous fecal nitrogen. Arch. Tierernaehr. 28:155-164.

Lapierre, H., and G. E. Lobley. 2001. Nitrogen recycling in the ruminant: a review. J. Dairy Sci. 84 (E. Suppl.):E223-E236.

Lapierre, H., J. P. Blouin, J. F. Bernier, C. K. Reynolds, P. Dubreuil, and G. E. Lobley. 2002. Effect of supply of metabolizable protein on whole body and splanchnic protein metabolism in lactating dairy cows. J. Dairy Sci. 85:2631-2641.

Leng, R. A., and J. V. Nolan. 1984. Symposium: Protein Nutrition of the Lactating Dairy Cow: Nitrogen Metabolism in the Rumen. J. Dairy Sci. 67:1072-1089.

Leterme, P., A. Théwis, E. François, P. Van Leeuwen, B. Wathelet, and J. Huisman. 1996. The use of ${ }^{15} \mathrm{~N}$-labeled dietary proteins for determining true ileal amino acid digestibilities is limited by their rapid recycling in the endogenous secretions of pigs. J. Nutr. 126:2188-2198.

Lien, K. A., W. C. Sauer, and M. E. R. Dugan. 1997. Evaluation of the ${ }^{15} \mathrm{~N}$-isotope dilution technique for determining the recovery of endogenous protein in ileal digesta of pigs: effect of the pattern of blood sampling, precursor pools and isotope dilution technique. J. Anim. Sci. 75:159-169.
Lobley, G. E., A. Connell, E. Milne, A. M. Newman, and T. A. Ewing. 1994. Protein synthesis in splanchnic tissues of sheep offered two levels of intake. Br. J. Nutr. 71:3-12.

McGuire, M. A., D. K. Beede, M. A. DeLorenzo, C. J. Wilcox, G. B. Huntington, C. K. Reynolds, and R. J. Collier. 1989. Effect of thermal stress and level of feed intake on portal plasma flow and net fluxes of metabolites in lactating Holstein cows. J. Anim. Sci. 67:1050-1060.

Matthews, D. E., J. M. Conway, V. R. Young, and D. M. Bier. 1981. Glycine nitrogen metabolism in man. Metabolism 30:886-893.

Nakamura, T., and F. G. Owen. 1989. High amounts of soyhulls for pelleted concentrate diets. J. Dairy Sci. 72:988-994.

National Research Council. 1989. Nutrient requirements of dairy cattle. 6th ed. Natl. Acad. Press, Washington, DC.

National Research Council. 2001. Nutrient Requirements of Dairy Cattle. 7th ed. Natl. Acad. Press, Washington, DC.

Newbold, C. J., B. Teferedegne, H.-S. Kim, G. Zuur, and G. E. Lobley. 2000. Effects of protozoa on nitrogen metabolism in the rumen of sheep. Abstr. Reprod. Nutr. Dev. 40:199.

Nyachoti, C. M., C. F. M. de Lange, B. W. McBride, and H. Schulze. 1997. Significance of endogenous gut nitrogen losses in the nutrition of growing pigs: a review. Can. J. Anim. Sci. 77:149-163.

Oldick, B. S., J. L. Firkins, and R. A. Kohn. 2000. Compartmental modeling with nitrogen-15 to determine effects of degree of fat saturation on intraruminal N recycling. J. Anim. Sci. 78:24212430.

Ørskov, E. R., and N. A. MacLeod. 1982. The flow of N from the rumen of cows and steers maintained by intraruminal infusion of volatile fatty acids. Abstr. Proc. Nutr. Soc. 41:76A.

Ørskov, E. R., and N. A. MacLeod. 1983. Flow of endogenous N from the rumen and abomasum of cattle given protein-free nutrients. Abstr. Proc. Nutr. Soc. 42:61A.

Papet, I., N. Lezebot, F. Barre, M. Arnal, and A. E. Harper. 1988. Influence of dietary leucine content on the activities of branchedchain amino acid aminotransferase (EC 2.6.1.42) and branchedchain alpha-keto acid dehydrogenase (EC 1.2.4.4) complex in tissues of preruminant lambs. Br. J. Nutr. 59:475-483.

Read, W. W., R. A. Harrison, and D. Halliday. 1982. A resin-based method for the preparation of molecular nitrogen for ${ }^{15} \mathrm{~N}$ analysis from urinary and plasma components. Anal. Biochem. 123:249-254.

Robinson, P. H., and J. J. Kennelly. 1990. Evaluation of a duodenal cannula for dairy cattle. J. Dairy Sci. 73:3146-3157.

SAS User's Guide: Statistics, Version 6.12 Edition. 1996. SAS Inst., Inc., Cary, NC.

Sarwar, J., J. L. Firkins, and M. L. Eastridge. 1991. Effect of replacing neutral detergent fiber of forage with soyhulls and corn gluten feed for dairy heifers. J. Dairy Sci. 74:1007-1017.

Sauer, W. C., S. C. Stothers, and R. J. Parker. 1977. Apparent and true availabilities of amino acids in wheat and milling by-products for growing pigs. Can. J. Anim. Sci. 57:775-784.

Schulze, H., P. Van Leeuwen, M. W. A. Verstegen, and J. W. O. Van den Berg. 1995. Dietary level and source of neutral detergent fiber and ileal endogenous nitrogen flow in pigs. J. Anim. Sci. 73:441-448.

Schulze, H., P. Van Leeuwen, M. W. A. Verstegen, J. Huisman, W. B. Souffrant, and F. Ahrens. 1994. Effect of level of dietary neutral detergent fiber on ileal apparent digestibility and ileal nitrogen losses in pigs. J. Anim. Sci. 72:2362-2368.

Siddons, R. C., J. V. Nolan, D. E. Beever, and J. C. MacRae. 1985. Nitrogen digestion and metabolism in sheep consuming diets containing contrasting forms and levels of N. Br. J. Nutr. 54:175-187.

Smith, R. H., and A. B. McAllan. 1974. Some factors influencing the chemical composition of mixed rumen bacteria. Br. J. Nutr. $31: 27-34$.

Souffrant, W. B., R. Köhler, and G. Gebhardt. 1982. Détermination de l'azote endogène dans les contenus digestifs par la technique isotopique $\left({ }^{15} \mathrm{~N}\right)$. Pages 175-187, In Physiologie digestive chez le porc. Les Colloques de l'INRA, no. 12, Ed. INRA Publ.

Storm, E., D. S. Brown, and E. R. Ørskov. 1983. The nutritive value of rumen micro-organisms in ruminants. 3 : The digestion of micro- 
bial amino and nucleic acids in, and losses of endogenous nitrogen from, the small intestine of sheep. Br. J. Nutr. 50:479-485.

Tamminga, S., H. Schulze, J. Van Bruchem, and J. Huisman. 1995. The nutritional significance of endogenous n-losses along the gastro-intestinal tract of farm nimals. Arch. Anim. Nutr. 48:9-22.

Van Bruchem, J., L. J. G. M. Bongers, S. C. W. Lammers-Wienhoven, G. A. Bangma, and P. W. M. Van Adrichem. 1989. Apparent and true digestibility of protein and amino acids in the small intestine of sheep as related to the duodenal passage of protein and nonprotein dry matter. Livest. Prod. Sci. 23:317-327.

Van Bruchem, J., J. Voigt, T. S. C. W. Lammers-Wienhoven,. U. Schönhusen, J. J. M. H. Ketelaars, and S. Tamminga. 1997. Secretion and reabsorption of endogenous protein along the small intestine of sheep: estimates derived from ${ }^{15} \mathrm{~N}$ dilution of plasma nonprotein-N. Br. J. Nutr. 77:273-286.

Van Soest, P. J., J. B. Robertson, and B. A Lewis. 1991. Methods for dietary fiber, neutral detergent fiber, and nonstarch polysaccharides in relation to animal nutrition. J. Dairy Sci. 74:3583-3597.
Waldo, D. R., and B. P. Glenn. 1984. Comparison of new protein systems for lactating dairy cows. J. Dairy Sci. 67:1115-1133.

Weidner, S. J., and R. J. Grant. 1994. Soyhulls as a replacement for forage fiber in diets for lactating dairy cows. J. Dairy Sci. 77:513-521.

Yu, F., L. A. Bruce, A. G. Calder, E. Milne, R. L. Coop, F. Jackson, G. W. Horgan, and J. C. MacRae. 2000. Subclinical infection with the nematode Trichostrongylus colubriformis increases gastrointestinal tract leucine metabolism and reduces availability of leucine for other tissues. J. Anim. Sci. 78:380-390.

Zebrowska, T., and J. Kowalczyk. 1991. Nitrogen secretion into isolated loops of the small intestine in conscious sheep. J. Anim. Physiol. A: Anim. Nutr. 65:133-139.

Zuur, G., D. R. Ouellet, H. Lapierre, and G. E. Lobley. 2001. A model for estimating endogenous nitrogen losses across the rumen. Abstracts of communications, Proc. 33rd Mtg. Agric. Res. Modelers' Group. J. Agric. Sci. (Camb.) 137:117-118. 